\title{
Mutậwầsith
}

\begin{tabular}{|c|c|c|}
\cline { 2 - 3 } \multicolumn{1}{c|}{ JURNAL } & HUKUM & ISLAM \\
\hline Vol. 4. No. 2 (2021) 129-149 & E-ISSN: : 2723-4681 & P-ISSN: 2722-2764 \\
\hline \multicolumn{3}{|c|}{ Published online on the journal's website: } \\
http://jurnal.iailm.ac.id/index.php/mutawasith
\end{tabular}

\section{Fenomena Hukum Islam di Masa Modern; Upaya Harmonisasi antara eksistensi dan Relevansi}

\author{
Jihad Khufaya, Muhammad Kholil, Nurrohman Syarif
}

Universitas Islam Negeri Sunan Gunung Djati Bandung, Indonesia

jihadkhufaya@gmail.com, cepkholil97@gmail.com, nurrohmansyarif1@gmail.com

\begin{tabular}{|c|c|c|}
\hline Received: & Revised: & Published: \\
\hline 23-11-2021 & $06-12-2021$ & $2-2021$ \\
\hline \multicolumn{2}{|r|}{ DOI: https://doi.org/10.47971/mjhi.v4i2.366 } \\
\hline
\end{tabular}

\begin{abstract}
The term modern, can be used for people, time, art, things, thoughts, culture and behavior. Modern ideas are often understood as ideas of renewal and are contrasted with traditional ideas. In the treasury of Islamic sciences, figh (Islamic law) is one of the classical disciplines that is always loaded with interesting discourses, the natural character of Islamic law as part of Islamic Shari'ah which is divine and permanent (qath'i) and must be accepted. "taken for granted" on the one hand and its position as a product of ijtihadi which is often produced from relatively Islamic sources (zhanny), on the other hand makes Islamic law have a different face. In other words, Islamic law is often identical with the number of Islamic rules and doctrines regarding a number of static and standardized daily problems of Muslims. However, it often gives birth to various nuances of new thinking, in response to the emergence of a number of contemporary challenges and problems that make Islamic law seem dynamic. How far is the existence of Islamic law with its stability without being trapped in a stagnant attitude, and whether Islamic law in modern times is still relevant to Islamic law revealed by Allah SWT. and to what extent it must accommodate the various dynamics of new thinking without having to reduce the eternal and universal values and principles of Islam, is very important to put forward.
\end{abstract}

Keywords: Modern, Challenges, Existence, Relevance and Islamic Law

\section{Abstrak}

Istilah modern, bisa digunakan pada orang, waktu, seni, benda, pemikiran, kebudayaan dan tingkah laku. Gagasan modern sering dipahami sebagai gagasan pembaharuan dan dipertentangkan dengan gagasan tradisional. Dalam khazanah ilmu-ilmu Islam, figh (Hukum Islam) merupakan salah satu disiplin ilmu klasik yang senantiasa sarat dengan wacana yang menarik, watak alamiah Hukum Islam sebagai bagian dari Syari'at Islam yang bersifat Ilahiyah dan permanen (qath'i) serta harus diterima secara "taken for granted" di satu sisi dan posisinya sebagai produk ijtihadi yang acapkali dihasilkan dari sumber-sumber Islam yang relatif (zhanny), di sisi lain menjadikan hukum 
Islam memiliki wajah yang berbeda. Dengan kata lain, hukum Islam sering identik dengan jumlah aturan dan doktrin Islam tentang sejumlah persoalan keseharian ummat Islam yang bersifat statis dan baku. Namun, ia acapkali melahirkan berbagai nuansa pemikiran baru, sebagai respon atas munculnya sejumlah tantangan dan persoalan kontemporer yang membuat hukum Islam terkesan dinamis. Sejauhmana Eksistensi Hukum Islam dengan stabilitasnya tanpa harus terjebak pada sikap jumud (stagnan), dan apakah Hukum Islam di masa modern masih relevansi dengan Hukum Islam yang diturunkan oleh Allah Swt. serta sebatas apa ia mesti mengakomodasi berbagai dinamika pemikiran baru tanpa harus mereduksi nilai-nilai dan prinsip-prinsip Islam yang abadi dan universal, menjadi amat penting untuk dikemukakan.

Kata Kunci : Modern, Tantangan, Eksitensi, Relevansi dan Hukum Islam

\section{A. PENDAHULUAN}

Zaman senantiasa melaju dengan pesat bagaikan roda yang berputar terus menerus tanpa henti-hentinya. Dalam perputaran itu, selalu terjadi perubahan (change) sebagai konsekuensi dari arus perkembangan pemikiranmanusia dalam rangka mencari cara baru untuk meningkatkan kesejahteraan hidupnya. Perubahan menuju kepada perkembangan (modern), banyak menimbulkan persoalan baru, terutama karena bias dari kemajuan sains dan teknologi. Perkembangan modern tersebut melahirkan berbagai macam bentuk perubahan, baik secara struktural maupun kultural. Sarjono Soekanto dalam bukunya Sosiologi Suatu Pengantar menyatakan bahwa perubahan-perubahan sosial adalah suatu variasi dari cara-cara hidup yang telah diterima, yang disebabkan baik karena perubahan yang disebabkan kondisi geografis, kebudayaan materiil, komposisi penduduk, ideologi maupun karena adanya difusi maupun penemuan-penemuan baru dalam masyarakat. ${ }^{1}$

Dalam era modernisasi ini, salah satu aspek pemikiran yang ikut mengalami tuntutan respon dan perubahan adalah bidang hukum Islam, dimana banyaknya persoalan-persoalan baru yang muncul pada abad modern ini, yang belum dijelaskan dalam nash al-Qur'anHadits, bahkan oleh para Fuqaha. Dalam menghadapi persoalan inilah, penafsiran dan upaya penemuan hukum dan ahli hukum Islam sangat dituntut. Karena nash al- al-Qur'an Hadits tidak begitu saja disosialisasikan untuk meresponi persoalan kultural, atau berlaku hanya pada waktu tertentu saja, tapi juga diperuntukan buat seluruh masyarakat (pada waktu tertentu), sampai hari kiamat.

Yusuf Qardawi menyatakan bahwa kondisi masyarakat yang selalu berubah dan berkembang, akan senantiasa melahirkan masalah-masalah baru yang memerlukan jawaban secara pasti tentang status hukumnya, terutama zaman sekarang ini, ijtihad menjadi lebih dibutuhkan, karena terjadi perubahan luar biasa dalam kehidupan sosial setelah revolusi industri. ${ }^{2}$

Rasulullah saw dalam menyampaikan ajaran Islam kepada ummat manusia telah memberikan kebebasan kepada manusia (cendekiawan-ulama) yang memenuhi syarat (kualifikasi) untuk memikirkan dan mencarikan solusi terhadap berbagai problem hidup yang dihadapi ummat manusia sebagaimana sabda Rasulullah yang disampaikan oleh Aisyah

\footnotetext{
${ }^{1}$ Sarjono Soekanto, Sosiologi Suatu Pengantar, (Jakarta: Rajawali, 1999) hlm. 23

2 Yusuf Al-Qardhawy, Tentang ljtihad Kontemporer, Alih Bahasa: Ahmad Syathori, (Jakarta: Bulan Bintang, 1987), hlm. 132

Jihad Khufaya, Muhammad Kholil, Nurrohman Syarif
} 
R.A., jika sesuatu (berhubungan) dengan urusan duniamu, maka hal itu diserahkan kepadamu, dan jika sesuatu itu (berhubungan) dengan urusan agamamu, maka harus diserahkan kepadaku.

Dari hadits Rasulullah ini dapat dipahami bahwa masalah-masalah yang menyangkut persoalan muamalah yang meliputi pengembangan ilmu pengetahuan dan teknologi, maka posisi nash al-Qur'an-Hadits lebih banyak mengarahkan dengan ayat-ayat yang bersifat umum ('am) dan mujmal yang masih memungkinkan untuk diinterprestasikan dan diperluas pemahaman maknanya sehingga sesuai dengan tuntutan perubahan zaman. Atas dasar itu, maka penelitian ini bertujuan untuk mencari hukum Islam senantiasa relevan luas dan up to date. Hukum Islam tidak statis, sempit dan ketinggalan zaman, sebagaimana anggapan sebagian orang, termasuk pandangan sebagian orientalis yang kurang mengerti hukum Islam.

\section{B. METODE}

Dalam penelitian ini penulis mengemukakan Hukum Islam di era Modern menggunakan metode kualitatif dengan pendekatan deskriptif analitif yuridis. Adapun sasaran dalam penelitian ini adalah eksistensi hukum Islam dan relevansinya. Teknik pengumpulan pada penelitian ini adalah studi pustaka, hal ini dilakukan dengan cara mengumpulkan data yang relevan atau sesuai yang dibutuhkan untuk penelitian, artikel ilmiah, jurnal, maupun sumber kredibel lainnya yang reliabel dan juga sesuai dengan topik penelitian yang dilakukan.

\section{PEMBAHASAN}

\section{Konsep Hukum Islam}

Istilah hukum Islam tidak ditemukan dalam literatur Islam, dan pada prinsipnya para pakar hukum Islam tidak mempergunakan kata "hukum Islam," untuk menterjemahkan sistem hukum yang bersumber dari ajaran Islam. Para pakar lebih memeilih menggunakan istilah Syari'ah, Fikih, dan Qanun, untuk menyebut hukum yang diderivasikan dari ajaran Islam. ${ }^{3}$ Kata hukum Islam baru muncul ketika para orientalis Barat mulai mengadakan penelitian terhadap ajaran Islam termasuk sistem hukumnya dengan menggunakan terma Islamic Law yang secara harfiah dapat diterjemahkan dalam bahasa Indonesia dengan hukum Islam.

Perlu juga dipahami bahwa, menurut Abdul Ghofur Anshori, pada mulanya para orientalis berpendapat bahwa pengertian 'syari'ah' dan 'fikih' itu adalah sama, juga pengertian syari'ah (dalam artian luas) dengan dinul Islam memiliki makna yang sama, yaitu paham tentang ajaran-ajaran Islam secara keseluruhan. Namun pendapat ini dalam perkembangannya kemudian mengalami perubahan, para ahli hukum Islam kemudian memberikan pengertian yang berbeda dan spesifik antara syari'ah dan fikih, yakni syariah

\footnotetext{
${ }^{3}$ Mardani, "Kedudukan Hukum Islam dalam Hukum Nasional," dalam Jurnal Hukum, Vol. 2, (2009), hlm. 270.

Jihad Khufaya, Muhammad Kholil, Nurrohman Syarif 
merupakan hukum Allah yang bersifat qath'i (absolut), sedangkan fikih, merupakan bagian (turunan) dari syariah yang bersifat dzanni (relatif). ${ }^{4}$

Hukum Islam diturunkan sebagai wahyu dari Allah, tetapi dalam proses transformasinya diperlukan 'agen' penyampai untuk menjadi mediator antara sumber sakral dari langit dengan kehidupan manusia. Dalam konteks inilah, Muhammad saw. dipercaya sebagai Nabi untuk menjadi agen penyampai yang mampu membahasan ajaran Islam dalam bahasa masyarakat awam. Dengan demikian peran nabi dalam Islam sangatlah besar. Ia tidak hanya sebagai utusan Tuhan tetapi juga teladan manusia dalam menjalankan hukum Tuhan. Pada aspek inilah kemudian perilaku dan sabda nabi juga menjadi bagian penting dalam sistem hukum Islam, atau yang disebut sunnah atau hadist. Sehingga juga menjadi sumber hukum kedua setelah al-Qur'an.

Dari kedua sumber itulah para ahli hukum Islam mengembangkan sistem hukum yang dalam literatur Islam disebut syari'ah. Diambil dari istilah bahasa Arab yang bermakna jalan. Syari'ah merepresentasikan jalan hidup yang telah didesain oleh Allah dan rasul-Nya untuk kehidupan umat Islam. Syari'ah didefinisikan sebagai apa yang disyariatkan oleh Allah kepada hamba-Nya baik berupa akidah, ibadah, akhlak, muamalah, maupun aturan-aturan hidup manusia dalam berbagai aspek kehidupannya untuk mengatur hubungan umat manusia dengan Tuhan mereka dan mengatur hubungan mereka dengan sesama mereka serta untuk mewujudkan kebahagiaan mereka di dunia dan di akhirat. Di samping itu, syari'ah juga mencakup hukum-hukum Allah bagi tiap-tiap perbuatan manusia, yakni halal, haram, makruh, sunnah, dan mubah. Derivasi dari syariah dalam berbagai konsep hukum teknis dan aplikatif ini kemudian disebut figh atau fikih. ${ }^{5}$

Semula syari'ah mempunyai arti luas yang mencakup akidah (teologi, prinsip-prinsip moral (etika dan karakter Islam, akhlak), dan peraturan-peraturan hukum (fikih). Pada abad kedua hijriah (abad ke-9 Masehi), ketika formulasi teologi dikristalkan untuk pertama kali dan kata syariah mulai dipakai dalam pengertian yang sistematis, syariah dibatasi pemakaiannya untuk menyebut hukum (peraturan-peraturan hukum) saja, sedang teologi dikeluarkan dari cakupannya. Jadi, syariah menjadi konsep integratif tertinggi dalam Islam. Pengkhususan syari'ah pada hukum 'amaliyyah saja atau dibedakannya dari dinn (agama), karena agama pada dasarnya adalah satu dan berlaku secara universal, sedang syariah berlaku untuk masing-masing umat dan berbeda dengan umat-umat sebelumnya. ${ }^{6}$

Dengan demikian, syari'ah lebih khusus dari agama, atau dengan kata lain agama mempunyai cakupan yang lebih luas dari syari'ah, bahkan bisa dikatakan bahwa syari'ah merupakan bagian kecil dari agama. Hal ini selaras dengan definisi yang diberikan para pakar hukum Islam semisal Wahbah al-Zuhaili, Muhammad Yusuf Musa, dan al-Tahanwy, terkait syari'ah sebagai setiap hukum yang disyariatkan oleh Allah kepada hamba-Nya baik melalui al-Qur'an maupun Sunnah. Artinya, syari'ah lebih khusus dari agama. Definisi inilah

${ }^{4}$ Abdul Ghofur Ansori, Hukum Islam; Dinamika dan pelaksanaannya Di Indonesia, (Yogyakarta: Total Media, 2008), hlm. 15-18.

${ }^{5}$ Abu Zahrah, Ushul Fiqh, (Jakarta: Pustaka Firdaus, 2006), hlm. 3-4.

${ }^{6}$ Amir Syarifuddin, Pembaharuan Pemikiran dalam Hukum Islam, (Padang: Angkasa Raya, 1993), hlm. 14.

Jihad Khufaya, Muhammad Kholil, Nurrohman Syarif 
yang juga diberikan Mahmud Syaltout terhadap syari'ah. Namun, Syaltout menambahkan bahwa syariah merupakan cabang dari aqidah yang merupakan pokoknya. Keduanya mempunyai hubungan yang sangat erat, integral dan tidak bisa dipisahkan. ${ }^{7}$

Syari'ah Islam dalam perjalanan sejarahnya memiliki kedudukannya yang amat penting. Hukum Islam tidak kehilangan fungsinya dalam kehidupan masyarakat yang terus menerus berkembang dengan terus bertransformasi dalam sesuai kultur dan budaya, sehingga dengan sendirinya dapat memenuhi kebutuhan masyarakat Islam. Karakteristik hukum Islam memang sangat fleksibel dalam segala aspek dan dapat mengikuti perkembangan jaman, walaupun didasarkan pada al-Qur'an yang sudah dibuat beribu-ribu tahun yang lalu dan tidak dapat diubah. Persebaran negara-negara yang menganut sistem hukum Islam banyak dijumpai di negara-negara jazirah Arab. Tidak hanya itu, negara-negara di Asia dan Afrika Timur banyak yang menganut sistem Hukum Islam baik secara langsung maupun mengalami proses resepsi dengan sistem hukum lainnya. ${ }^{8}$

Sumber hukum utama dan tertinggi hukum Islam adalah al-Qur'an, kitab suci umat muslim yang berasal dari Tuhan. Berikutnya dalam hierarki sumber hukum Islam terdapat Sunnah, yang merupakan penjelasan tentang ucapan, perbuatan, dan tingkah laku Nabi (termasuk sikap diam beliau terhadap pertanyaan-pertanyaan tertentu). Sunnah kerap dijadikan aturan untuk persoalan-persoalan yang tidak disebutkan dalam al-Qur'an. Sumber hukum selanjutnya adalah ljma', yaitu pendapat-pendapat yang diterima secara umum di kalangan ulama, terutama cendekiawan hukum dalam menafsirkan dua sumber hukum utama tadi.44 Selain itu juga terdapat terdapat sumber hukum yang disebut Qiyas, yaitu penalaran dengan logika, terutama terkait persoalan-persoalan kontemporer untuk menghasilkan regulasi untuk situasi yang tidak secara langsung dicakup sumber-sumber dasar. ${ }^{9}$

Oleh karenanya hukum Islam dipahami sebagai institusi yang tidak berakar maupun dicangkokkan pada sosiologi. Hukum Islam merupakan sarana mengabdi kepada Tuhan, dan bukan kepada masyarakat. meskipun pada aspek teknisnya sangat memahami kondisi masyarakat. Prinsip yang bekerja disini adalah manusialah yang harus menaati hukum dan bukan hukum yang harus diciptakan sesuai dengan keinginan manusia. Oleh karena itu hukum Islam didesain sangat konprehensif dan berlaku sepanjang zaman. ${ }^{10}$ Termasuk persoalan hubungan dengan Tuhan ( $h a b /$ min Alläh), hubungan sesama manusia (habl min an-nās), termasuk refleksi hubungan manusia dengan Tuhan. ${ }^{11}$ Konsep inilah yang sulit dipahami oleh sebagian besar orang Barat.

Dengan kondisi demikian, hukum Islam di sini meliputi syariah dan fikih. Hukum Islam sangat berbeda dengan hukum Barat yang membagi hukum menjadi hukum privat (hukum perdata) dan hukum publik. Sama halnya dengan hukum adat di Indonesia, hukum Islam

\footnotetext{
${ }^{7}$ Mahmud Syaltut, Al-Islam Aqidah wa Syari'ah, Cet. III (Mesir: Dar al-Qalam, 1966), hlm. 12-13.

${ }^{8}$ LukmanSantoso, Perbandingan Siste Civil Law dan ukum Islam serta Interakinya dalam Sistem Hukum Indonesia, Jurnal Hukum, Vol. 13, No. 2, (2016), hlm. 202

${ }^{9}$ Fathurrahman Djamil, Filsafat Hukum Islam, (Jakarta: Logos Wacana IImu, 1999), hlm. 82.

$10 \mathrm{lbid}, \mathrm{hlm} .79$

${ }^{11}$ Ratno Lukito, Hukum..., hlm. 76.
}

Jihad Khufaya, Muhammad Kholil, Nurrohman Syarif 
tidak membedakan hukum privat dan hukum publik. Pembagian bidang-bidang kajian hukum Islam lebih dititikberatkan pada bentuk aktivitas manusia dalam melakukan hubungan. Dengan melihat bentuk hubungan ini, dapat diketahui bahwa ruang lingkuphukum Islam ada dua, yaitu hubungan manusia dengan Tuhan (hablunminallah) dan hubungan manusia dengan sesamanya (hablun minannas). Bentuk hubungan yang pertama disebut ibadah dan bentuk hubungan yang kedua disebut muamalah.

\section{Masa Modern Persfektif Sejarah Islam}

Periode setelah abad ke- $13 \mathrm{H} / 19 \mathrm{M}$ lumrah disebut sebagai periode modern dalam kajian sejarah Islam. Dalam konteks ini kata 'modern' digunakan sebagai kata sifat yang menunjukkan satu rentangan waktu sebagai kelanjutan dari periode klasik dan periode pertengahan. Maka ketika disebutkan kata 'Islam Modern', yang dimaksudkan adalah fenomena historis Islam yang terjadi sejak tahun 1800 hingga saat ini. Sebuah periode sejarah tentu saja terbentuk karena adanya perubahan yang serius dan substantif. Para pengkaji sejarah Islam pada umumnya menyarankan tiga periode dimaksud sebagai mewakili masa kemajuan pesat (klasik), masa kemandekan (pertengahan), dan kebangkitan kembali (modern). Jika gerak dinamika naik-turunnya sejarah Islam digambarkan dengan sebuah kurva, maka periode modern mewakili garis tanjakan yang kedua. ${ }^{12}$

Dalam konteks sejarah Islam, modernitas jelas menjadi tujuan atau cita-cita utama dalam dua abad terakhir. Ini dikatakan dengan tetap mengingat adanya perbedaanperbedaan yang terkadang sangat tajam tentang apa yang dimaksud dengan modernitas tersebut. Rangkaian pengupayaan yang dilakukan untuk mencapai modernitas itu disebut sebagai modernisasi. Modernisasi dapat diposisikan sebagai tema besar sejarah Islam periode modern. Modernisasi merambah semua aspek kehidupan umat Islam tanpa kecuali. Modernisasi berlangsung di semua wilayah Dunia Islam, meskipun dengan intensitas dan tingkat kemajuan yang saling berbeda. ${ }^{13}$

Dalam sejarah hukum Islam, masa modern disebut juga masa kebangkitan kembali atau pasca masa stagnasi (jumud) hukum Islam. Masa ini dimulai pada abad $13 \mathrm{H} / 19 \mathrm{M}$ hingga sekarang ini, yang ditandai dengan menepisnya fanatisme mazhab dan usaha keras fuqaha dan mujtahidin untuk menghidupkan kembali kajian fiqh. ${ }^{14}$

Secara ringkas dapat dijelaskan kondisi objektif hukum Islam yang terbagi pada enam periode. Periode pertama adalah hukum Islam pada masa Rasulullah saw. Periode kedua adalah hukum Islam pada masa Khulafaurrasyidin. Periode ketiga adalah hukum pada masa Tabi'in. Periode keempat, adalah hukum Islam pada masa keemasan, munculnya empat mazhab fiqih dalam Islam; Mazhab Hanafi, Maliki, Syafie dan Hambali. Periode kelima adalah hukum Islam pada masa stagnasi (jumud). Pada periode ini muncul fatwa ulama yang terkenal bahwa "Pintu ljtihad telah Tertutup" dan terjadilah fanatisme yang berlebihan terhadap mazhab-mazhab tertentu. Periode ini juga ditandai dengan lemahnya kekuasaan

12 Hasan Asari, Sejarah Islam Modern: Agama dalam Negoisasi Historis Sejak Abad XIX, (Medan: Perdana Pusblishing, 2019), hlm. 14

13 Ibid, h. 16

${ }^{14}$ Min'min A Sirry, Sejarah Figh Islam, sebuah pengantar, (Surabaya: Risalah Gusti, 1996), hlm. 20

Jihad Khufaya, Muhammad Kholil, Nurrohman Syarif 
kaum muslimin dan terpecah belahnya kekuatan mereka. Periode keenam adalah hukum Islam pada masa kebangkitan kembali. Masa ini dimulai pada abad 13 H/19 M hingga sekarang ini, yang ditandai dengan menepisnya fanatisme mazhab dan usaha keras fuqaha dan mujtahidin untuk menghidupkan kembali kajian fiqh. ${ }^{15}$

\section{Kondisi Objektif Hukum Islam Masa Modern}

Pada masa modern, akar diskriminasi perempuan dalam masyarakat Muslim adalah konsepsi untuk mempertahankan cara pandang jurisprudensi klasik (figh) secara literalistik dalam legislasi nasional. Hal ini merupakan adaptasi terhadap pengaruh dari transplantasi sistem hukum Barat di negara-negara Muslim yang menghilangkan karakteristik sistem legal Islam. Independensi yurisprudensi model klasik sulit ditemui dalam konteks legislasi legal modern yang mensyaratkan otoritas politik sebagai satu-satunya pembentuk hukum. Hilangnya konsepsi demikian dalam realitas politik dan legislasi legal modern membuat sistem legal dan judisial Islam cenderung berubah menjadi otoritarian dan rigid. Kecenderungan interpretasi skriptural dalam legislasi legal merupakan salah satu bentuk pemertahanan hasil-hasil pendapat mujtahid, disharmoni politik dan segregasi relijius, dan kolonialisme imperialisme, apologetisme dan diskursus HAM Islam. ${ }^{16}$

Menurut Hallaq, alasan atas kondisi ini adalah kejadian tragis yang terjadi pada abad 19, dimana pembentukan negara bangsa di dunia Muslim yang dengannya, legalisasi yurisprudensi klasik Islam segera ditinggalkan dan sistem legal Eropa ditransplantasi dimana-mana sebagai akibat penjajahan. ${ }^{17}$ Hukum Islam kemudian menjadi tiga bagian besar. Pertama, hukum Islam disekularisasikan. Kedua, sekularisasi khususnya bahwa hukum, pengalaman Muslim dialienasi. Ketiga, sekularisasi melalui kodifikasi atas inisiatif tirani di dunia Muslim. Secara partikular, kategorisasi adopsi hukum legal Eropa membuat sistem legal Islam kemudian hanya dialienasi dan didomestikasi menjadi "keluarga hukum politik" (political law family) karena praktek hukum profesionalnya merupakan subjek hegemoni politik, seperti pengaruh dari pemimpin dan kontrol dari hakim. ${ }^{18}$ Wael B. Hallaq menyatakan bahwa ide dan entusiasme mengenai hukum Islam sebagai sistem legal modern patut dipertanyakan karena perubahan konsepsi otoritas legal sehubungan dengan kemunculan konsep negara bangsa dan perubahan konsepsi legal. ${ }^{19}$

Pada umumnya, hukum Islam di negara-negara muslim mengikuti preskripsi skriptural, bahkan pada negara-negara dengan sistem legal sekular. Disini para ulama beserta lembaga fatwa cenderung bersikap apologis terhadap perkembangan zaman dan perubahan konsepsi legal. Hukum Islam yang secara historis lebih mengarah pada nilai substansi, dan tidak membutuhkan pengakuan formal negara untuk wajib diberlakukan

\footnotetext{
15 Ibid., hlm. 21

${ }^{16}$ El-Fadl, Khaled Abou. "The human rights commitment in modern Islam." Zainah Anwar ed. Wanted: equality and justice in the Muslim family. Musawah, 2009, hIm. 156.

17 Aini, Noryamin. "Inter-religious marriage from socio-historical Islamic perspectives." BYU L. Rev. (2008), hlm. 669.

18 Abu-Odeh, Lama. "The Politics of (Mis) recognition: Islamic Law Pedagogy in American Academia." The American Journal of Comparative Law, 2004, hlm. 789-824.

${ }^{19}$ Barazangi, Nimat H. "The Absence of Muslim Women in Shaping Islamic Thought: Foundations of Muslims" Peaceful and Just Co-existence." JOURNAL of Law and Religion, 24.2, 2008, hlm. 56.
}

Jihad Khufaya, Muhammad Kholil, Nurrohman Syarif 
kemudian pada masa modern berubah menjadi hukum Islam yang kaku yang membutuhkan institusionalisasi dan formalisasi oleh negara. Dalam konteks ini, sebagian masyarakat muslim dengan dukungan ulama dan lembaga fatwa konservatif merubah kekuasaan fatwa menjadi koersif. Secara konseptual fatwa merupakan opini legal dan tidak mempunyai kekuatan mengikat dan koersif, sehingga tidak ada kewajiban bagi umat muslim untuk melaksanakan putusan dari fatwa. Hal yang menarik dalam regulasi berbasis syariat di Indonesia pada masa modern, sebagaimana pula di negara-negara mayoritas muslim lainnya, adalah bahwa fatwa dan ulama masih mempunyai kekuatan legal dalam masyarakat Muslim. Dalam konteks hubungan ulama-masyarakat muslim yang berpola patron-klien, maka fatwa juga dapat berarti ketundukan terhadap putusan ulama. Di sisi lain, negara masih mengakui lembaga fatwa untuk turut membentuk opini legal. Fenomena yang terjadi dalam kasus pengundangan berbagai regulasi berbasis syariat di Indonesia oleh pemerintah di berbagai daerah di Indonesia, menunjukkan bahwa otorisasi fatwa sebagai lembaga legal terjadi karena legitimasi yang diberikan oleh negara atau pemerintahan lokal sebagai pengakuan dalam keahlian dalam bidang relijius yang diiringi dengan pandangan kewajiban untuk mematuhinya dan mengejawentahkannya dalam bentuk regulasi formal. ${ }^{20}$

Setelah negara-negara muslim dapat membebaskan diri satu persatu dari jeratan penjajahan Barat, mereka pun menyatakan kemerdekaan, serta mendirikan negara sendiri dengan kedaulatan penuh. Bentuk negara yang didirikan bermacam-macam, mulai dari republik, kerajaan, dan ada pula yang berbentuk pemerintahan gabungan (seperti Uni Emirat, dan Malaysia). Beberapa negara yang menjadikan Islam sebagai dasar negara, dan juga mengikuti negara- negara modern, yang menggunakan azas non-agama (sekuler). ${ }^{21}$ Hukum, merupakan tulang punggung atas berdirinya sebuah negara, tanpa adanya hukum, mustahil negara bisa tegak berdiri. Namun, masing-masing negara itu berbeda beda tentang hukum yang mana yang akan dipakai dan diterapkan di negaranya.

Menurut pengamatan J.N.D. Anderson yang dikutif Yayan, ada tiga pola negaranegara muslim memberlakukan hukum Islam, yaitu: ${ }^{22}$

a. Negara yang masih mengakui hukum Islam sebagai hukum asasi dan menerapkannya secara utuh. Sumber hukum yang dijadikan landasannya adalah AlQur'an, sunnah, ljma, Qiyas dan pendapat para fuqaha. Diantara negara-negara yang masih mempertahankan hukum Islam tersebut adalah Saudi Arabia, Nigeria Utara, Oman, Republik Islam Iran dan Afganistan.

b. Negara yang meninggalkan hukum Islam dan menggantikannya dengan hukum sekuler, karena Islam hanya mengatur masalah ritual keagamaan yang sangat privat, tidak mengatur masalah agama secara luas termasuk mengatur masalah negara. Turki merupakan negara satu-satunya yang melakukan hal tersebut.

${ }^{20}$ Abdul Ghofur dan Sulitiyono, Peran Ulama dalam Legislasi Modern Hukum Islam, Jurnal Asy-Syir'ah, Vol. 49, No. 1 (2014), hlm. 282

${ }^{21}$ Yayan Sopian, Tarikh, hlm. 160

22 lbid, hlm. 160

Jihad Khufaya, Muhammad Kholil, Nurrohman Syarif 
c. Negara yang mengkompromikan kedua sistem hukum, yaitu hukum Islam dan hukum sekuler. Yakni menjadikan hukum Islam sebagai salah satu bagian dari sistem hukum negara. Sebagian besar negara-negara Islam mengambil langkah ini seperti Indonesia, Malaysia, Syria, Mesir, Pakistan dll. Namun sayang, hukum Islam yang diambil dan menjadi hukum perundang- undangan itu, sebagian besar hanya menyentuh hukum perdata tertentu saja, sementara hukum pidana Islam belum tersentuh dan masih memakai hukum pidana Barat.

Penggunaan hukum Islam yang digunakan di negara-negara muslim hanya sebatas hukum keluarga saja, mengingat rentannya posisi hukum tersebut di kalangan umat Islam. ${ }^{23}$ Seperti yang digambarkan oleh An-Naim, mengutip Herbert Liebesny, bahwa pergantian hukum Islam tersebut membentuk satu "paradigma lima lingkaran konsentris", di mana hukum dagang adalah hukum yang paling banyak dipengaruhi oleh Barat, kemudian hukum pidana, hokum pertanahan, hukum kontrak, baru setelah itu dalam lingkaran terakhir adalah hukum keluarga. ${ }^{24}$ Pun demikian dengan Turki, meskipun tergolong negara yang paling besar dan paling awal melakukan sekulerisasi, tetapi dalam hukum keluarga tetap memberikan peluang bagi masyarakatnya untuk menggunakan hukum keluarga Islam. Dan hal inilah yang memunculkan dualisme penerapan hukum di dunia muslim. ${ }^{25}$

Dalam melihat hukum dan perubahan sosial inilah penting untuk diuraikan di sini tentang perbedaan ulama. Ulama berada dalam dua kecenderungan yang seringkali dilihat secara dikotomis. Kelompok pertama, berpendapat bahwa Syariah normatif sangat terbatas jumlahnya, sementara persoalan-persoalan hukum dan kemanusiaan tidak akan pernah berakhir dan tidak pernah ada batasnya (al-nushus mutanahiyyah wa al-waqai' ghairu mutanahiyah). Karena itu, Syariah yang merupakan hukum Tuhan harus dijaga agar tetap berada pada posisi ilahiyah-nya, dengan cara melaksanakan secara "harfiyyat" apa yang tertulis dalam teks suci itu, sementara perkembangan masyarakat dapat diselesaikan dengan jalur pemahaman terhadap teks suci sesuai dengan perkembangan tradisi masyarakat muslim. Dalam hal ini, dibedakan antara syariah dan fikih.

Sedangkan kelompok kedua berpendapat bahwa Syariah normatif dengan sendirinya dapat dijadikan acuan oleh setiap masyarakat dalam keragaman tradisi dan budaya, berusaha memahami norma Syariah yang ada pada priode Madinah sebagai norma dasar yang jiwanya harus digali dan diimplementasikan dalam kehidupan umat Islam, seusai dengan kondisi yang beragam. Dalam pencariannya, mereka memfokuskan pada dua hal, pertama, menjadikan norma syariah sebagai nilai moral dan etika sosial, dan kedua, mencari akar kemaslahatan yang melandasi norma syariah di Madinah. Dalam hal ini, Syariah tidak hanya menjadi sumber hukum semata, tetapi lebih dari itu sebagai landasan

23 Daniel S. Lev, Peradilan Agama Islam di Indonesia. Penerjemah Zaini Ahmad Noeh, (Jakarta: Intermasa, 1986), cet. II, hlm. 285.

${ }^{24}$ Abdullah Ahmed An-Naim, Dekonstruksi Syariah. Penerjemah Ahmad Suaedy dan Amiruddin arRany, (Yogykarta: Elkis, 2004), cet. IV, hIm. 11.

${ }^{25}$ Azyumardi Azra, Syariat Islam dalam Bingkai Nation State, hlm. 44.

Jihad Khufaya, Muhammad Kholil, Nurrohman Syarif 
dan sumber nilai, serta moral sosial Islam, sehingga keadilan, kebebasan, kesetaraan, dan persamaan menjadi nilai universal syariah. ${ }^{26}$

Menjelang abad 21, kondisi hukum Islam sudah sangat berbeda dengan situasi dan kondisi hukum Islam pada masa Rasulullah, sampai masa keemasannya. Hukum Islam sudah tertinggal oleh hukum Barat. Bangsa Eropa yang dahulu mengenal peradaban dan pikiran Yunani berkat jasa para ilmuwan Arab Islam, justru telah lebih maju dari dunia Islam, baik dari segi ekonomi, politik, budaya, maupun hukumnya. Banyaknya negaranegara yang bermunculan di dunia Islam, sejak berakhirnya perang dunia kedua, termasuk Republik Indonesia, yang notabene berpenduduk terbesar di dunia, namun tetap memakai hukum Barat, baik perdata maupun pidana. Hanya aspek hukum keluargalah seperti perkawinan, perceraian, pembagian warisan dan perwakafan yang masih diterapkan itupun dengan berbagai modifikasi.

\section{Tantangan Hukum Islam Masa Modern}

a. Tantangan Internal

Hukum Islam yang ada sekarang, pada umumnya merupakan hasil ijtihad ulama terdahulu, yaitu hasil ijtihad para ulama masa keemasan hukum Islam periode keemasan yang sejak awal abad kedua sampai pertengahan abad keempat hijriyah. Para ulama yang datang kemudian, sudah merasa puas dengan hasil ijtihad para ulama terdahulu, mereka tidak membutuhkan lagi ijtihad baru, mereka cukup menerapkan hasil ijtihad yang sudah ada. ${ }^{27}$

Apabila dicermati secara seksama, secara internal ada beberapa faktor yang menjadi tantangan hukum Islam di masa modern, yaitu :

1) Hukum Islam bercampur baur dengan hukum adat setempat. Tidak dapat dipungkiri, bahwa hukum Islam dapat bercampur-baur dengan hukum adat (daerah setempat), karena masuknya Islam di suatu daerah mengakibatkan terjadi interaksi sosial dengan masyarakat setempat yang telah memiliki akar adat dan budaya yang begitu kuat. Proses intraksi yang berlangsung begitu lama, sehingga dalam masyarakat, terkadang sulit dibedakan mana hukum Islam yang murni, mana hukum adat setempat dan mana hukum yang sudah bercampur dengan hukum adat setempat, karena mereka menganggap adat (urf) merupakan salah satu metode pengambilan hukum, sehingga keberadaannya tidak dapat dipisahkan dalam sistem hukum Islam.

2) Hukum Islam umumnya tidak berlaku pada negara yang mayoritas berpenduduk muslim. Tidak berlakunya hukum Islam secara formal pada negara-negara yang mayoritas Islam seperti Indonesia, merupakan suatu yang menarik diteliti, padahal dalam ajaran Islam, terdapat penekanan untuk menerapkan hukum Islam bila sedang memutuskan suatu perkara.

${ }^{26}$ Fathurrahman Djamil, Karakteristik Pemikiran Figh Prof. Dr. Satria Effendi, M. Zein, MA, Epilog dalam Satria Ef- fendi, Problematika Hukum Keluarga Islam Kontemporer, hlm. 524.

${ }^{27}$ Iskandar Usman, Istihsan dan Pembaharuan Hukum Islam, (Depok: Grafindo Persada, 1994), hIm. 171

Jihad Khufaya, Muhammad Kholil, Nurrohman Syarif 
3) Belum munculnya kader mujtahid yang serius. Belum munculnya kader mujtahid yang serius, sebagai bukti masih adanya rasa enggan untuk berijtihad di kalangan mujtahid, karena hampir semua persolaan fiqh yang muncul sudah dibahas oleh ulama-ulama fiqh terdahulu melalui buku-buku fiqh yang diterbitkan. Di samping itu, calon ulama dan ulama-ulama Islam lebih banyak tertarik pada wilayah politik praktis, apalagi disinyalir wilayah ini cukup menjanjikan dalam hal profit. Sedangkan wilayah fiqh, masih dianggap kering dan lemah dari sisi profit.

4) Belum adanya kepercayaan kepada penegak hukum. Belum adanya kepercayaan kepada penegak hukum khususnya penegak hukum dari lembaga-lembaga peradilan Islam, hal itu terjadi karena kurangnya publikasi dengan baik dari lembaga ini tentang eksistensi dan peranannya dalam menegakkan hukum Islam secara formal. Sehingga ummat Islam lebih banyak memilih untuk menyelesaikan masalahnya. Disamping itu para penegak hukum (hakim) sudah banyak yang terkontaminasi dengan istilah mafia peradilan, sogok menyogok dan lainlain. Sehingga citranya sudah tidak baik dimata masyarakat.

5) Dunia Islam masih menganggap rendah hukum dan sarjana hukum Islam. Pandangan dunia Islam yang masih menganggap rendah hukum dan sarjana hukum Islam lebih disebabkan oleh kuatnya dominasi hukum Barat (orientalis) dalam dunia Islam, sehingga timbul sikap remeh terhadap eksistensi hukum, sehingga menjadikan sarjana hukum Islam merasa tidak memiliki percaya diri dan otoritas yang penuh untuk melakukan ijtihad secara serius.

6) Bahasa hukum Islam Kuno. Pengunaan bahasa hukum Islam masih terkesan kuno, karena istilah-istilah (term) hukum umumnya sudah dimonopoli oleh hukum Barat, sehingga istilah-istilah hukum Islam menjadi tersisihkan.

7) Dalam konteks Indonesia, hukum Islam yang cocok dengan daerah tertentu belum tentu cocok dengan daerah lain. Hukum Islam yang dirumuskan dalam kitab-kitab fiqih klasik juga belum tentu cocok dengan kondisi masa kini. Oleh karena itu qonunisasi atau orang menyebut formalisasi hukum Islam berpotensi mengekang perkembangan hukum Islam yang selalu berkembang akibat dibukanya pintu ijtihad. Sebab hukum Islam yang ditetapkan oleh Negara dalam bentuk qanun akan cepat ketinggalan zaman. Contohnya adalah Kompilasi Hukum Islam yang dilegalkan atau disahkan penggunaannya melalui instruksi presiden pada tahun 1991. Kompilasi yang baru berumur satu setengah dasa warsa ini telah menuai banyak kritik dari banyak intelektual muda Islam di Indonesia karena beberapa bagiannya sudah tidak relevan dengan perkembangan zaman. ${ }^{28}$

b. Tantangan Ekternal

Ada dua real eksternal yang dihadapi hukum Islam dalam perjalanan sejarahnya hingga saat ini. Pertama, Pandangan negatif dari sebagian orientasi tentang eksistensi

\footnotetext{
${ }^{28}$ Nurrohman, Hukum Islam di Era Demokrasi: Tantangan dan Peluang bagi Reformasi Politik Syari'at Islam di Indonesia, Jurnal Addin, Vol. 9, No. 1 (2015), hlm. 171
}

Jihad Khufaya, Muhammad Kholil, Nurrohman Syarif 
hukum Islam, dan kedua : munculnya berbagai masalah-masalah baru yang membutuhkan ketetapan hukum yang cepat dan tepat.

Ada sejumlah orientasi yang mengkritisi hukum Islam karena ketakutannya. Diantara orientasi yang memberikan kritikan itu adalah :

1) N.J. Coulson

Dalam bukunya A History of Islamic Law, Coulson mengatakan, ekposisi klasik menggambarkan puncak suaratu proses dimana istilah-istilah spesifik hukum diekspresikan sebagai kehendak Tuhan yang tidak dibatalkan. Sebagai kebalikan dari sistem-sistem hukum yang didasarkan pada akal manusia. Hukum Tuhan semacam ini memiliki dua karakteristik khusus yang utama. Pertama, ia merupakan sistem kekal dan abadi, yang tidak mudah dimodifikasi dengan berbagi otoritas legislatif. Kedua, karena berbagai perbedaan orang yang membentuk dunia Islam, syi'ah sebagai hukum Tuhan mewakili standar keseragaman tentang berbagi sistem hukum merupakan produk akan manusia yang didasarkan pada situasi lokal dan kebutuhan-kebutuhan kelompok suatu masyarakat tertentu. ${ }^{29}$

Selanjutnya dikatakan bahwa Yurisprudensi Islam hanya dapat berhasil memecahkan masalah hukum dan masyarakat, jika bebas dari tujuan hukum agama yang diekspresikan dalam pengertian totaliter. ${ }^{30}$ Dari pernyataan di atas, seolah-olah ia mengatakan bahwa hukum Islam tidak dapat dijadikan dasar hukum untuk mengatur atau mengontrol masyarakat.

2) Kerr

Menurut Kerr, hukum Islam bersifat idealitas dan terhindar dari positipisme. Dengan gamlang ia mengatakan: "Kepentingan bangkit kembali orang-orang Islam modern dalam teori klasik tentang khalifah dan usaha untuk menemukan di dalamnya dasar-dasar bagi Lembaga-lembaga demokrasi, "progresif". Kedaulatan yang bersifat umum dan lain-lain, tidak hanya dirangsang oleh pertemuan politik Timur dan Barat beberapa abad yang lalu, tetapi juga didorong oleh publikasi orientalis. ${ }^{31}$

Kelihatannya ia menemukan kekeliruan pada semangat para ahli hukum yang idealis, dimana perhatian utama mereka dalam menafsirkan hukum Islam adalah untuk mempertahankan bentuk ideal menghindari metode-metode yang mengubah kehendak nilai-nilai yang diwahyukan. Baik Cuolson maupun Kerr adalah penganut positivisme. Secara prinsip mereka concern pada kepentingan materiil masyarakat dan menganggap hukum Islam adalah suatu yang bersifat agamis, dan bukan hukum dalam pengertian modern. ${ }^{32}$

3) Jhon Shamson

Dalam bukunya, Encountring Islamic Law, sebagaimana dikutip oleh Rifyal Ka'bah, mengatakan, hukum Islam telah dalam kesarjanaan Anglo Amerika sebagai sebuah sistem hukum yang tidak sempurna secara mendasar. Bidang kritik telah berubah dari

\footnotetext{
${ }^{29}$ N.J. Coulson, A History of Islamic Law, Endiburg:1964, hIm. 5-6

${ }^{30} \mathrm{lbid}$, hlm. 225

${ }^{31}$ Kerr, Islamic Eeforms, California 1996, hlm. 19

32 Muhammad Muslehuddin, Philosophy of Islamic Law and The Orientalis. Delhi; Makazi Maktaha Islam 1995, hlm. 88
}

Jihad Khufaya, Muhammad Kholil, Nurrohman Syarif 
mempertahankan pemerintahan kolonial selama masa imperialisme kepada dakwaan kontemporer atas hak-hak asasi manusia, demokrasi dan pluralisme. Permasalahan dengan kritik ini ialah bahwa ia memantulkan hubungan kekuatan antara Eropa (Amerika Serikat) dan dunia Islam. Argumen yang mengatakan hukum Islam itu tidak sempurna menyegarkan persepsi bahwa Eropa itu lengkap. Sebagai akibatnya, keterkaitan tulus dengan hukum Islam menjadi problematik, karena setiap orang yang mencoba ke arah itu ditarik ke dalam bidang peraturan orientalis. ${ }^{33}$

Permasalahan sekarang bagi peneliti Islam tidak hanya mengkaji ulang kajian Barat terhadap Islam, tetapi juga mengkaji Barat itu sendiri yang telah mendominasi peradaban dunia dan melahirkan berbagai masalah di dunia Islam. Pandangan orientalis di atas, berangkat dari pendekatan yang keliru terhadap hukum Islam. Mereka tidak memahami bahwa al-Quran sebagai sumber rujukan utama telah menegaskan bahwa Allah SWT telah memberikan isyarat dengan jelas menyangkut keharusan tegaknya supremasi hukum di muka bumi ini, sebagaimana dinyatakan dalam surah Al-Jaatsiyah ayat 18, kemudian Kami jadikan engkau (Muhammad) mengikuti syariat (peraturan) dari agama itu, maka ikutilah (syariat itu) dan janganlah engkau ikuti keinginan orang-orang yang tidak mengetahui.

Meskipun demikian bukanlah berarti bahwa pandangan orientalis itu sama sekali tidak ada positifnya. Minimal munculnya pandangan-pandangan tersebut, akan meransang dan memotivasi cendekiawan muslim khususnya ahli hukum Islam untuk lebih intens mengkaji secara mendalam dan filosofis tentang hukum Islam, serta senantiasa berusaha dan memperbaharui pemikirannya sesuai dengan tuntutan kemajuan zaman. Bila hal tersebut tidak dilakukan maka tidak heran jika orientalis akan memahami kandungan Islam di dunia Barat lebih komprehensif dan memiliki metodologi dan pendekatan yang lebih modern.

Tantangan hukum Islam eksternal yang lain adalah munculnya berbagai macam persoalan-persoalan baru di abad modern ini sebagai konsekuensi dari perkembangan peradaban manusia, yang menuntut jawaban dan ketetapan hukum dengan segera, misalnya munculnya fenomena cybersex yang kini sedang melanda dunia, praktik cloning atau masalah beredarnya pil penghancur janin (aborsi) merek RU-486, yang baru-baru ini disahkan pemakaiannya oleh pemerintah Amerika Serikat, yang katanya telah melalui perdebatan selama 12 tahun. Pemakaian pil aborsi tersebut akan memudahkan proses aborsi, tanpa harus ditangani oleh dokter atau dukun.

\section{Upaya yang Dilakukan pada Masa Modern}

Beberapa upaya yang dilakukan ulama untuk menghadapi tantangan dan sebagai pembaharuan hukum Islam di masa modern, di antaranya:

a. Adanya ajakan untuk melakukan ijtihad, yang merupakan keharusan, dan bukan larangan. Dan meyakinkan bahwa ijtihad itu sekarang sangat diperlukan untuk memberikan jawaban bagi tantangan jaman, jika menginginkan Islam masih tetap eksis. Adanya upaya untuk menggali lagi khazanah Islam yang sudah terpendam di

${ }^{33}$ Rifyal Ka'bah. Oksidentalisme, Sikap Kita Terhadap Tradisi Barat, (Paramadina, Jakarta, 2000), hlm.3 Jihad Khufaya, Muhammad Kholil, Nurrohman Syarif 
dasar samudera pengetahuan, selain juga menolak taklid yang telah berumur ratusan tahun. ${ }^{34}$

b. Merubah strategi ijtihad, dari ijtihad fardhi (individu) kepada ijtihad jam'i (kolektif). Hal ini, untuk menjawab keluhan ulama pada masa jumud dan taqlid bahwa ulama tidak akan mampu melakukan ijtihad dengan cara fardhi (individu).

c. Pembersihan ajaran-ajaran Islam dari takhayyul dan khurafat. Hal ini, menjadi trend pada masa awal kebangkitan Islam modern, kemudian melahirkan kelompokkelompok Islam modern, seperti Muhammadiyah di Yogyakarta, Thawalib di Padang, al-Irsyad di Jakarta, Persatuan Islam (PERSIS) di Bandung ${ }^{35}$, sampai sekarang kelompok Islam ini masih nyaring menyuarakan revivalisme. ${ }^{36}$

d. Adanya studi lintas mazhab (Muqaran madzahib). Hal ini berguna untuk membuka baut kevakuman yang sudah karatan, membuka tabir/kabut kefanatikan, untuk menghadirkan saling mengetahui dan saling pengertian sehingga melahirkan sikap toleransi antar mazhab. Bahkan, lebih jauh, dengan adanya dialog antar mazhab ini ternyata memberikan efek ganda, yakni dapat memecahkan persoalan yang hadir dengan berbagai strategi pemecahan dilihat dari berbagai perspektif mazhab fiqh. Dari dorongan adanya dialog antar mazhab fiqh ini, lahirlah kajian-kajian muqoronah al-madzahib yang tidak saja melakukan dialog antara mazhab fiqh sunni, melainkan juga diadakan dialog antara sunni- syi'i. Dari kajian ini pula, setidaknya reaktualisasi hukum Islam di negara-negara muslim mampu bertahan dalam perubahan sosial masyarakat yang semakin pesat. ${ }^{37}$

e. Adanya studi lintas agama (perbandingan agama), sehingga tampil ilmu perbandingan agama. Ilmu ini berusaha untuk melahirkan sikap saling mengetahui dan saling mengerti sehingga diharapkan lahirnya sikap toleransi antar pemeluk agama. $^{38}$

f. Adanya studi tentang kritik matan hadis (tidak seperti masa-masa sebelumnya hanya terfokus pada kritik sanad). Upaya tersebut dilakukan tidak luput dari munculnya penggunaan hermeunetik dalam penafsiran, sehingga para penafsir seringkali membawa teks-teks tersebut dalam satu konteks masyarakat Arab klasik. Dalam hal ini, tidak sedikit hadis-hadis yang dianggap sebagai manifestasi dari budaya Arab, sehingga validitasnya pun harus dipertanyakan. ${ }^{39}$

g. Adanya propaganda modernisasi melalui media: ${ }^{40}$

${ }^{34}$ Fauzan Saleh, Teologi Pembaruan: Pergeseran Sunni di Indonesia Abad XX, (Jakarta: Serambi, 2001),

35 Howard M. Federspiel, dalam Labirin Ideologi Muslim: Pencarian dan Pergulatan Persis di Era. Penerjemah Ruslani dan Kurniawan Abdullah, (Jakarta: Serambi, 2004), hlm. 12.

${ }^{36}$ Fazlur Rahman, Islam. Penerjemah Senoaji Soleh, (Jakarta: Bina Aksara, 1987), hlm. 312;

${ }^{37}$ Musdah Mulia, Pembaruan Hukum Keluarga di Indonesia, dalam Komaruddin Hidayat dan Ahmad Gaus (ed), Islam, Negara dan Civil Society, (Jakarta: Paramadina, 2005), hlm. 305

38 Yayan Sopian, Tarikh Tasyri Sejarah Pembentukan Hukum Islam, (Depok: PT Raja Grafindo Persada, 2018), hlm. 158

39 Fatima Mernissi, Penafsiran Feminis tentang Hak-hak Perempuan, dalam Charles Khurzman, Wacana Islam Liberal, hlm. 156

40 Yayan Sopian, Tarikh,... hlm. 159

Jihad Khufaya, Muhammad Kholil, Nurrohman Syarif 
a. Media massa misalnya, yang dikembangkan oleh Jamaluddin al-Afgani, Muhammad Abduh al-Urwah al-Wusqo, kemudian Muhammad Abduh dan Rasyid Ridha dengan majalah "al-Manar" nya, di mana majalah ini sangat berpengaruh dan memberikan pencerahan bagi umat Islam, khususnya kaum muslim yang masih terbelenggu oleh penjajahan Barat. Tidak sedikit dibahas dalam media massa itu masalah-masalah pembaharuan tentang hukum Islam, khususnya ajakan untuk melakukan reaktualisasi hukum Islam, sehingga relevan dengan perkembangan zaman.

b. Mendirikan pendidikan (formal non formal), misalnya dengan berdirinya Aligard University dan Islamic Recearch Institute yang lahir dari gagasan Syah Waliyullah Ad-Dihlawi. Tujuan dari lembaga ini adalah memungkinkan kaum muslimin Pakistan hidup sesuai dengan ajaran al-Qur'an dan sunnah, dalam cahaya perkembangan modern dan sepadan dengan tantangan zaman. Sekolah Galatasaray di Turki yang awal pendiriannya bertujuan untuk mengejar ketertinggalan Islam dari Barat. Sedangkan al-Azhar, yang merupakan perguruan tingi Islam tertua, melakukan modernisasi pendidikan khususnya pada kepemimpinan Muhammad Abduh. ${ }^{16}$ Selain itu, tumbuh juga pendidikan non-formal di pondok-pondok pesantren (khususnya pondok pesantren modern) yang menawarkan pengkajian pemikiran modern dan melakukan komparasi hukum dan mazhab.

c. Lembaga sosial kemasyarakatan, seperti al-Ikhwan al-Muslimun di Mesir yang didirikan oleh Said Hawa, Liga Muslim yang didirikan oleh Ali Jinah di Pakistan, Muhammadiyyah, Nahdhatul Ulama, Al- Wasliyah, Thawalib dan Persis di Indonesia. Keberadaan lembaga sosial kemasyarakatan seperti itu, merupakan sarana dakwah yang efektif dan efesien kerena langsung berhubungan dengan masyarakat, baik masyarakat tingkat bawah maupun masyarakat tingkat atas. Dalam masalah hukum misalnya, masing-masing lembaga itu mempunyai lembaga pengkajian hukum tersendiri yang cukup berwibawa dan mengikat bagi para pendukungnya, misalnya Nahdhatul Ulama mempunyai lembaga Bahsul Masa'il, Muhammadiyaah mempunyai lembaga Tarjih, Persis membunyai lembaga Hisbah.

\section{Upaya Unifikasi, Kodifikasi Legislasi, dan Formaslisasi Hukum Islam}

Selain upaya yang dijelaskan di atas, upaya unifikasi, kodifikasi, legislasi dan formalisasi hukum Islam menjadi sorotan di masa modern ini. Sejak awal periode sejarah pembentukan hukum Islam, perdebatan tentang apakah hukum Islam perlu ditetapkan atau diundangkan oleh Negara sudah muncul. Ide kodifikasi hukum pertama kali dicanangkan oleh Abu Muhammad Ibnu al- Muqaffa (102-139 H/720-757 M) ketika ia menjadi sekretaris negara pada masa pemerintahan khalifah Abu Ja'far al-Mansur (754-775). la mengajukan ide tersebut kepada khalifah kerena pengamatannya terhadap kekacauan hukum dan peradilan ketika itu. Pada masa itu sentimen mazhab sudah mulai merajalela, sehingga masing-masing mazhab hanya bertahan dan bangga dengan mazhab imamnya. Akibatnya, 
taqlidpun membabi buta, bukan hanya di kalangan rakyat biasa melainkan juga di kalangan ulama, bahkan lebih jauh di kalangan para hakim sendiri. Dari keadaan seperti itu muncul pernyataan bahwa tidak ada lagi ulama yang mampu berijtihad dan para hakim tidak perlu lagi berijtihad, tetapi cukup merujuk kepada kitab-kitab mazhab. Hal ini mendorong Ibnu alMuqaffa untuk mengusulkan ide itu melalui bukunya yang berjudul Risalah al Sahabah. ${ }^{41}$

Ada beberapa tujuan yang hendak dicapai dengan ide kodifikasi hukum tersebut, antara lain untuk memberikan batasan yang jelas tentang hukum sehingga mudah untuk disosialisasikan di tengah-tengah masyarakat dan untuk membantu hakim dalam merujuk hukum mana yang akan diterapkannya terhadap kasus yang dihadapi tanpa harus melakukan ijtihad lagi. Dalam kaitan ini, kodifikasi hukum diharapkan mampu mengatasi kekacauan hukum pada saat itu dan menghindarkan subjektivitas hakim di lembagalembaga peradilan. Akan tetapi, ide ini tidak mendapat dukungan dari pihak penguasa, karena muncul kekhawatiran apabila terjadi kesalahan berijtihad di satu pihak dan keharusan bertaklid di pihak lain. ${ }^{42}$

Menetapkan norma-norma syari'at Islam melalui legislasi atau qanunisasi mengandung aspek positip dan aspek negative. Aspek positifnya bisa memberikan standar hukum Islam yang relative seragam. Tapi aspek negatifnya bisa mengurangi kebebasan hakim dalam memilih ketentuan hukum Islam yang paling cocok untuk kasus tertentu yang dia hadapi. Dalam tradisi Islam klasik, hakimlah yang membuat hukum. Tradisi dan sejarah hukum Islam lebih mirip dengan tradisi Common Law ketimbang Continental law. Tidak pernah ada kodifikasi hukum dalam sejarah hukum Islam sampai akhir dinasti Usmani. Kodifikasi hukum Islam di akhir dinasti Usmani adalah akibat dari pengaruh Eropa Continental. ${ }^{43}$

Ide kodifikasi hukum Ibnu al-Muqaffa baru terealisasi pad tahun 1293 H/1876 M di bawah pemerintahan Turki Usmani dengan lahirnya kodifikasi hukum Islam pertama dalam mazhab Hanafi. Kodifikasi hukum yang disebut sebagai Majallah al- Ahkam al-Adliyyah diberlakukan ke seluruh wilayah yang dikuasai oleh Turki Usmani pada saat itu sampai pertengahan abad ke-20. Setelah perang dunia II bermunculan kodifikasi hukum di berbagai negara Arab yang diawali oleh Mesir dan diikuti oleh Irak, Yordania, Libanon, Maroko, Tunisia, Sudan, Kuwait dan Uni Emirat Arab. ${ }^{44}$

Dilihat dari waktu kemunculannya, ide Ibnu al-Muqaffa tentang kodifikasi hukum baru mendapatkan jawaban setelah negara-negara Islam dijajah oleh barat. Untuk menghindari diri dari pengaruh hukum Eropa, para ulama dan pakar hukum di berbagai negara tersebut berupaya untuk melakukan kodifikasi hukum Islam walaupun hanya sebagian, khususnya di bidang hukum keluarga.

Dalam hubungannya dengan proses tranformasi dan legislasi di berbagai negara Islam dapat dijumpai adanya tiga tipe pembaharuan. Pertama, negara yang tidak

\footnotetext{
${ }^{41}$ Tim Penyusun, Suplemen Ensiklopedi Islam I (Jakarta : PT.Ichtiar Baru Van Hoeven, 2003), hIm. 336.

$42 \mathrm{lbid}, \mathrm{hlm} .336$

${ }^{43}$ Nurrohman, Formalisasi Syari'at Islam di Indonesia, Jurnal Ar-Risalah, Vol. 12, No. 1, (2012), hlm. 86

${ }^{44}$ Azyumardi Azra, Syariat Islam dalam Bingkai Nation State, dalam Komaruddin Hidayat dan Ahmad Gaus (ed), Islam, Negara dan Civil Society, hlm. 29
}

Jihad Khufaya, Muhammad Kholil, Nurrohman Syarif 
mengadakan pembaharuan dan memberlakukan hukum fiqih secara apa adanya. Contoh tipe negara ini adalah Arab Saudi. Kedua, negara yang telah menanggalkan sama sekali Islam dari dasar negaranya (sekuler) dan mengadopsi sistem hukum negara-negara Barat dalam konstitusinya, seperti yang dilakukan Republik Turki pasca-Khalifah Usmani. Negara seperti ini menangkap hukum Islam hanya dari aspek filosofinya saja. Ketiga, negara yang mencoba menggabungkan Islam dan sistem hukum lainnya, seperti dari Barat dalam konstitusinya. Contoh negara ini adalah Mesir, Tunisia, Indonesia dan Aljazair. ${ }^{45}$ Negara yang disebut terakhir cenderung menggabungkan atau mencari titik temu antara rumusan hukum Islam dengan filosofi hukumnya. ${ }^{46}$

\section{Peluang Relevansi Penerapan Hukum Islam di Indonesia}

Apabila diperhatikan, suara-suara kritis terhadap formalisasi syari'at Islam sebenarnya bukan ditujukan semata-mata pada aspek legislasi atau formalisasinya tapi lebih ditujukan kepada model pemahaman yang konservatif dari syari'at Islam. Model konservatif dari syari'at Islam umumnya adalah hasil pemahaman atau hasil ijtihad ulama masa lalu terhadap syari'at Islam. Ijtihad ulama masa lalu tentang syari'at Islam memang sudah banyak yang tidak relevan dengan perkembangan masa kini. Suara kritis terhadap formalisasi syari'at Islam juga muncul karena formalisasi syari'at Islam terkadang merambah sampai mengatur cara hidup atau style of life yang bersifat pribadi seperti cara orang berpakaian yang sebenarnya bukan merupakan ajaran Islam yang pokok. ${ }^{47}$

Hal-hal pokok yang mutlak perlu dilindungi oleh syari'at Islam menurut alSyatibi ada lima: agama, jiwa, keturunan (kelangsungan generasi), harta dan akal. Menurut al-Syatibi, perlindungan terhadap kelima hal ini mutlak (dlaruriyyat), karena kelima hal ini diperlukan untuk tegaknya kemashlahatan agama dan dunia. Dlaruriyat dalam pandangan al-Syatibi adalah sesuatu yang bila tidak dijalankan maka akan timbul kekacauan dan kesulitan yang nyata.

Perlindungan terhadap agama, bagi umat Islam mengandung pengertian bahwa umat mesti dilindungi dalam menjalankan rukun atau kewajiban agamanya mulai dari syahadat, shalat, zakat, puasa sampai dengan haji. Perlindungan terhadap agama juga mengandung pengertian agar agama dijaga kelestariannya dan dilindungi dari hal-hal akan merusaknya. Demikian pula perlindungan terhadap jiwa, keturunan, harta dan akal. Adapun menutup aurat atau hal-hal yang berkaitan dengan kesopanan dan keluhuran budi pekerti masuk kategori tahsiniyat. ${ }^{48}$

Oleh karena itu jika yang diformalkan adalah prinsip-prinsip umum syari'at Islam yang bisa membawa kemaslahatan bagi semua golongan maka formalisasi syari'at Islam tidak akan menimbulkan masalah. Tapi jika umat Islam mau

45 Muhammad Iqbal, Fiqh Siyasah; Kontekstualisasi Doktrin Politik Islam. (Jakarta, Gaya Media Pratama, 200I), hlm. 161

${ }^{46}$ Nurrohman, Syari'at Islam dan Hukum Nasional (Problematika Transformasi dan Integrasi Hukum Islalm Kedalam Hukum Nasional), Jurnal Tajitid, Vol. 26, No. 2, (2019), hlm. 10

${ }^{47}$ Nurrohman, Syari'at Islam..., hlm. 175

48 Asy-Syatibi, al-Muwafaqat, jilid 2, (Bairut: Dar al-Fikr, t.t.), hlm. 4-5

Jihad Khufaya, Muhammad Kholil, Nurrohman Syarif 
memformalkan hukum pidana Islam peninggalan masa lalu maka mereka harus berani melakukan reformasi dan reinterpretasi terhadap bagianbagian yang sudah tidak relevan dengan perkembangan masa kini agar bisa diterima dan kiranya bisa membawa maslahat bagi semua orang. Hukuman rajam (dilempari batu sampai mati) dan hukuman potong tangan tidak mungkin bisa diundangkan di Indonesia. ${ }^{49}$

Oleh karena itu dalam era modern peluang untuk memasukkan norma-norma yang berasal dari hukum Islam masih tetap terbuka sepanjang hukum Islam dipahami sesuai dengan tujuannya atau sesuai dengan maqashid asy-syari'ah-nya. Dalam era modern, syari'at Islam juga tetap memiliki peluang yang tinggi untuk dimasukkan dalam setiap pembuatan undang-undang sepanjang ijtihad untuk menggali atau menerapkan syari'at Islam agar sesuai dengan perkembangan zaman tetap dibuka seluas-luasnya. Meskipun tujuannya tidak berubah, sejarah membuktikan bahwa beberapa bagian dari syari'at atau hukum Islam mengalami evolusi. ${ }^{50}$

Dalam era modern setiap Muslim pada dasarnya memiliki peluang dan kesempatan yang sama untuk memahami dan menerjemahkan hukum-hukum Tuhan. Jadi bukan hanya para fuqaha dan penguasa saja yang bisa mengatasnamakan diri sebagai khalifatullah sebagimana yang sering dipahami selama ini. Oleh karena itu ijtihad mesti dimaknai sebaagi refleksi pemikiran dinamis manusia yang pada akhirnya mengarah pada konsensus atau kesepakatan. Fazlur Rahman mengatakan: ijtihad must be multiple effort of thinking minds-some naturally better than other, and some better than other in various areas-that confront each other in open arena of debate, resulting eventually in an overall consensus. ${ }^{51}$

\section{PENUTUP}

Kodisfikasi, Legislasi dan Formalisasi hukum Islam tampaknya menjadi suatu fenomena umum yang ditemuan di negara-negara berpenduduk Islam modern. Namun tidak sedikit menuai respon negatif dengan masih kurang relevannya kodifikasi hukum Islam tersebut. Untuk itu, diperlukan satu kegigihan dan kesungguhan dalam merumuskan kembali relevansi hukum Islam untuk konteks saat ini, karena tanpa hal itu hukum Islam justru akan sangat ditinggalkan oleh zaman. Konsekuensinya, hukum Islam justru tidak akan diterapkan oleh masyarakat. Alih-alih untuk menjadikan Islam sebagai rahmatan lil alamin, yang mengayomi semua kelompok, golongan dan penganut agama, umat Islam merasa acuh dengan doktrin hukum Islam yang dianggap ketinggalan zaman. Dalam hal ini, tugas para sarjana Syariah-lah untuk membangun satu konsep pemikiran hukum Islam yang mapan, dengan tetap memperhatikan prinsip Syariah, tradisi masyarakat dan perkembangan zaman yang selalu berubah. Umat Islam melanjutkan proses pengembangan hukum Islam, terutama dengan tema dan permasalahan yang baru muncul, seiring dengan

\footnotetext{
${ }^{49}$ Nurrohman, Syari'at Islam..., hlm. 176

50 lbid, hlm. 176

${ }^{51}$ Fazlur Rahman, Islam Challenges and Opportunies", dalam Alford T. Welch and Piere Cachia (ed.), Islam: Past Influence and Present Challenge, hlm. 148.
}

Jihad Khufaya, Muhammad Kholil, Nurrohman Syarif 
terbentuknya masyarakat modern (nation state). Dalam fase ini, umat Islam disibukkan dengan peradaban dan kebudayaan baru yang tidak dijumpai sebelumnya, terutama terkait dengan konstitusionalisme negara bangsa, seperti isu-isu negara Islam, hak asasi manusia, hak-hak perempuan, atau demokrasi. Untuk itu, diperlukan satu kegigihan dan kesungguhan dalam merumuskan kembali relevansi hukum Islam untuk konteks saat ini, karena tanpa hal itu hukum Islam justru akan sangat ditinggalkan oleh zaman. Konsekuensinya, hukum Islam justru tidak akan diterapkan oleh masyarakat. Alih-alih untuk menjadikan Islam sebagai rahmatan lil alamin, yang mengayomi semua kelompok, golongan dan penganut agama, umat Islam merasa acuh dengan doktrin hukum Islam yang dianggap ketinggalan zaman. Dalam hal ini, tugas para sarjana Syariah-lah untuk membangun satu konsep pemikiran hukum Islam yang mapan, dengan tetap memperhatikan prinsip Syariah, tradisi masyarakat dan perkembangan zaman yang selalu berubah.

\section{Daftar Pustaka}

A Sirry, Min'min. 1996. Sejarah Fiqh Islam, sebuah pengantar. Surabaya: Risalah Gusti.

Abdul Ghofur dan Sulitiyono. 2014. Peran Ulama dalam Legislasi Modern Hukum Islam. Jurnal Asy-Syir'ah.

Abu-Odeh, Lama. 2004, The Politics of (Mis) recognition: Islamic Law Pedagogy in American Academia.". The American Journal of Comparative Law

Aini, Noryamin. 2008. Inter-religious marriage from socio-historical Islamic perspectives.

Al-Qardhawy, Yusuf. 1987. Tentang ljtihad Kontemporer, Alih Bahasa: Ahmad Syathori. Jakarta: Bulan Bintang.

An-Naim, Abdullah Ahmed. 2004. Dekonstruksi Syariah. Penerjemah Ahmad Suaedy dan Amiruddin ar-Rany. Yogykarta: Elkis.

Ansori, Abdul Ghofur. 2008. Hukum Islam; Dinamika dan pelaksanaannya Di Indonesia. Yogyakarta: Total Media.

Asari, Hasan. 2019. Sejarah Islam Modern: Agama dalam Negoisasi Historis Sejak Abad XIX. Medan: Perdana Pusblishing.

Azra, Azyumardi. Tth. Syariat Islam dalam Bingkai Nation State, dalam Komaruddin Hidayat dan Ahmad Gaus (ed), Islam, Negara dan Civil Society.

Barazangi, Nimat H. 2008. "The Absence of Muslim Women in Shaping Islamic Thought: Foundations of Muslims" Peaceful and Just Co-existence." JOURNAL of Law and Religion

Djamil, Fathurrahman. 1999. Filsafat Hukum Islam. Jakarta: Logos Wacana IImu.

El Fadl, Khaled Abou. 2009. "The human rights commitment in modern Islam." Zainah Anwar ed. Wanted: equality and justice in the Muslim family. Musawah,

Ka'bah, Rifyal. 2000. Oksidentalisme, Sikap Kita Terhadap Tradisi Barat. Jakarta: Paramadina.

Kerr. 1996. Islamic Eeforms, California

M. Federspiel, Howard. 2004. Labirin Ideologi Muslim: Pencarian dan Pergulatan Persis di Era. Penerjemah Ruslani dan Kurniawan Abdullah. Jakarta: Serambi.

Mahmud Syaltut, Al-Islam Aqidah wa Syari'ah, Cet. III (Mesir: Dar al-Qalam, 1966), h. 1213.

Mardani. 2009. Kedudukan Hukum Islam dalam Hukum Nasional. Jurnal Hukum 
Mernissi, Fatima. Tth. Penafsiran Feminis tentang Hak-hak Perempuan, dalam Charles Khurzman, Wacana Islam Liberal

Muhammad Iqbal. 200I. Fiqh Siyasah; Kontekstualisasi Doktrin Politik Islam. Jakarta: Gaya Media Pratama

Mulia, Musdah. 2005 Pembaruan Hukum Keluarga di Indonesia, dalam Komaruddin Hidayat dan Ahmad Gaus (ed), Islam, Negara dan Civil Society. Jakarta: Paramadina.

Muslehuddin, Muhammad. 1995. Philosophy of Islamic Law and The Orientalis. Delhi; Makazi Maktaha Islam

N.J. Coulson, A History of Islamic Law, Endiburg :1964. Page 5-6

Nurrohman. (2019). Syari'at Islam dan Hukum Nasional (Problematika Transformasi dan Integ rasi Hukum Islalm Kedalam Hukum Nasional). Jurnal Tajitid.

2012. Formalisasi Syari'at Islam di Indonesia, Jurnal Ar-Risalah.

2015. Hukum Islam di Era Demokrasi: Tantangan dan Peluang bagi Reformasi Politik Syari'at Islam di Indonesia. Jurnal Addin.

Rahman, Fazlur. 1987. Islam. Penerjemah Senoaji Soleh. Jakarta: Bina Aksara.

S. Lev, Daniel. 1986. Peradilan Agama Islam di Indonesia. Penerjemah Zaini Ahmad Noeh. Jakarta: Intermasa.

Saleh, Fauzan. 2001. Teologi Pembaruan: Pergeseran Sunni di Indonesia Abad XX. Jakarta: Serambi

Santoso, Lukman. 2016. Perbandingan Siste Civil Law dan ukum Islam serta Interakinya dalam Sistem Hukum Indonesia. Jurnal Hukum

Soekanto, Sarjono. 1999. Sosiologi Suatu Pengantar. Jakarta : Rajawali

Sopian,Yayan. 2018. Tarikh Tasyri Sejarah Pembentukan Hukum Islam. Depok: PT Raja Grafindo Persada.

Syarifuddin, Amir. 1993. Pembaharuan Pemikiran dalam Hukum Islam Padang: Angkasa Raya.

Tim Penyusun. 2003. Suplemen Ensiklopedi Islam I. Jakarta : PT.Ichtiar Baru Van Hoeven. Usman, Iskandar 1994. Istihsan dan Pembaharuan Hukum Islam. Depok: Grafindo Persada. Zahrah, Abu. 2006. Ushul Fiqh. Jakarta: Pustaka Firdaus. 